\title{
The Voltage-Dependent Anion Channel (VDAC) of Pacific Oysters Crassostrea gigas Is Upaccumulated During Infection by the Ostreid Herpesvirus-1 (OsHV-1): an Indicator of the Warburg Effect
}

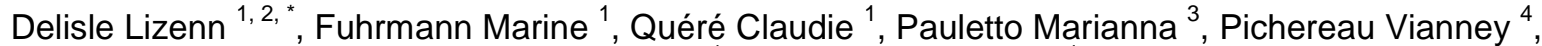 \\ Pernet Fabrice ${ }^{1}$, Corporeau Charlotte ${ }^{1}$
}

${ }^{1}$ Ifremer, UMR 6539 CNRS/UBO/IRD/Ifremer, Laboratoire des sciences de l'Environnement Marin (LEMAR), 29280 Plouzané, France

2 Ifremer, Laboratoire de physiologie des invertébrés (LPI), Unité de physiologie fonctionnelle des organismes marins (PFOM), Centre Ifremer de Bretagne, 1625 Route de Saint Anne, CS 10070, 29280 Plouzané, France

${ }^{3}$ Department of Comparative Biomedicine and Food Science, University of Padova, Viale dell'Università 16, 35020 Legnaro, Padova, Italy

${ }^{4}$ Université de Bretagne Occidentale, UMR 6539 CNRS/UBO/IRD/ Ifremer, Laboratoire des sciences de l'Environnement Marin (LEMAR), 29280 Plouzané, France

* Corresponding author : Lizenn, Delisle, email address : Lizenn.Delisle@ifremer.fr

\begin{abstract}
:
Voltage-dependent anion channel (VDAC) is a key mitochondrial protein. VDAC drives cellular energy metabolism by controlling the influx and efflux of metabolites and ions through the mitochondrial membrane, playing a role in its permeabilization. This protein exerts a pivotal role during the white spot syndrome virus (WSSV) infection in shrimp, through its involvement in a particular metabolism that plays in favor of the virus, the Warburg effect. The Warburg effect corresponds to an atypical metabolic shift toward an aerobic glycolysis that provides energy for rapid cell division and resistance to apoptosis. In the Pacific oyster Crassostrea gigas, the Warburg effect occurs during infection by Ostreid herpesvirus (OsHV-1). At present, the role of VDAC in the Warburg effect, OsHV-1 infection and apoptosis is unknown. Here, we developed a specific antibody directed against $C$. gigas VDAC. This tool allowed us to quantify the tissue-specific expression of VDAC, to detect VDAC oligomers, and to follow the amount of VDAC in oysters deployed in the field. We showed that oysters sensitive to a mortality event in the field presented an accumulation of VDAC. Finally, we propose to use VDAC quantification as a tool to measure the oyster susceptibility to OsHV-1 depending on its environment.
\end{abstract}

Keywords : Voltage-dependent anion channel, Warburg effect, Crassostrea gigas, Ostreid herpes virus 


\section{INTRODUCTION}

Since 2008, massive mortality events of young oysters C. gigas have been reported in France (Miossec et al. 2009; EFSA 2010; Barbosa Solomieu et al. 2015; Pernet et al. 2016). These mortality events are associated with the infection of oysters with a newly described genotype ( $\mu$ Var) of Ostreid herpesvirus 1 (OsHV-1) (Segarra et al. 2010). A causal relationship between OsHV-1 and oyster mortality has been established (Schikorski et al. 2011; EFSA 2015). OsHV-1 is a double strand DNA virus which belongs to Malacoherpesviridae family (Davison 2005; Segarra et al. 2010) and is now distributed along the European coastline from Portugal to Scandinavia, and closely related variants have been detected in Australia, New Zealand and Asia (EFSA 2015; Barbosa Solomieu et al. 2015; Pernet et al. 2016). Mortalities of juveniles range from 40 to $100 \%$, resulting in huge losses in Pacific oyster production (Pernet et al. 2012; Dégremont 2013).

To date, there is only limited data on how OsHV-1 interacts with its host, and the pathogenesis of the disease is not completely understood. The first study of this interaction, used global protein expression profiling to investigate the oyster cellular response to OsHV-1 infection, was carried out in 2014 (Corporeau et al. 2014). This study demonstrated that during early stages of infection ( 2 days after injection), several biological pathways were modulated and that infected oysters exhibited an increased glycolysis and accumulation of the protein Voltage-Dependent Anion Channel (Cg-VDAC) that reflected a "Warburg effect" (Corporeau et al. 2014). Recently, Li et al. further illustrated the up-regulation of the Cg-VDAC transcript in hemolymph of OsHV-1 infected oysters (Li et al. 2016).

The Warburg effect was first described by Otto Warburg in 1930s in cancer cells (Warburg 1956), and partly results from deregulation of cellular energy pathways (Poliseno 2012). Cells 
experiencing the Warburg effect show a metabolic shift toward an "aerobic glycolysis", which presents several benefits to support the high energy and macromolecular synthesis requirement in rapidly dividing cells (Pedersen 2007; Vander Heiden et al. 2009; Puyraimond-Zemmour and Vignot 2013). Several human viruses reprogram the host energy metabolism toward the Warburg effect to support the biosynthesis of viral building blocks (Mesri et al. 2014): Human Papillomavirus (HPV) (Guo et al. 2014), Human Cytomegalovirus (HCMV; $\beta$-Herpesvirus) (Munger et al. 2006), Kaposi's Sarcoma Herpesvirus (KSHV) (Delgado et al. 2010) or Hepatitis C virus (Diamond et al. 2010).

To date, the Warburg effect has been shown to occur in the shrimp Litopenaeus vannamei as a metabolic shift that provides cellular energy and building blocks during the replication phase of the White Spot Syndrome Virus (WSSV) (Chen et al. 2011; Su et al. 2014). The WSSV infection is a lethal disease that can cause up to $100 \%$ mortality in 10 days (Chen et al. 2011; Su et al. 2014). In Litopenaeus vannamei, the Warburg effect is an essential component of the host-viral interaction, providing essential energy for successful WSSV viral replication (Wang et al. 2010; Su et al. 2014).

The Voltage-Dependent Anion Channel (VDAC) is a mitochondrial protein that plays a pivotal role in normal cells, but is also involved in the Warburg effect, occurring with cancer and viral infection in mammals. In normal cells, VDAC is a major membrane protein located in the mitochondrial outer membrane that controls metabolism and apoptosis, and it is considered as a multiple stress sensor, being an apoptotic checkpoint during stress and pathological conditions (Lemasters and Holmuhamedov 2006; Martel et al. 2014; Brahimi-Horn et al. 2015). The VDAC pore mediates the transport of metabolites such as ADP, ATP and NADH, ions and even larger molecules up to 4-6 kDa (Rostovtseva et al. 2002; Naghdi and Hajnóczky 2016). This channel is a key protein that drives cellular energy metabolism by controlling the influx and efflux of 
metabolites and ions, and participates in mitochondrial membrane permeabilization (Martel et al. 2014). VDAC acts as a platform for many proteins supporting glycolysis and prevents apoptosis by interacting with hexokinase, or members of the Bcl-2 family, respectively. VDAC is thus involved in the metabolic reprogramming of cancer cells toward the Warburg effect (Mazure 2017). In shrimp, when the expression of VDAC is silenced by RNA interference (RNAi) before WSSV infection, the mortality decreases by $50 \%$, the detection of WSSV DNA drop markedly, and the Warburg effect does not occur (Wang et al. 2010; Chen et al. 2011). The accumulation of VDAC during infection has also been reported in some other species including the flounder Paralichtys olivaceus infected with the Scophtalmus maximus rhabdovirus (Lü et al. 2007), and during Grass carp hemorrhagic disease in the grass carp Ctenopharyngodon idella (Shen et al. 2014). In Crassostrea gigas infected by OsHV-1, both the mRNA (Renault et al. 2011; Li et al. 2016) and the protein VDAC (Corporeau et al. 2014; Young et al. 2017) were up-accumulated during the infection processes linked with the metabolic shift toward the Warburg effect (Young et al. 2017).

In this context, characterizing the $\mathrm{Cg}$-VDAC protein and quantifying its accumulation becomes a key component for following OsHV-1 infection processes in oyster. VDAC was recently described in oyster ( $\mathrm{Li}$ et al. 2016). Like other invertebrates, oysters have only one type of VDAC. Cg-VDAC clustered into the group of VDAC 2, strongly conserved gene from cnidarians to mammals. This study showed that VDAC transcripts were expressed during all oyster developmental stages and in all tissues at adult stage.

As a first step toward the study of VDAC functioning in infection processes of $C$. gigas, the objectives of the present study are: (1) producing and validating a specific antibody directed against $C$. gigas VDAC, (2) analyzing VDAC tissue-specific expression and electrophoretic profiles, and finally (3) assessing the VDAC amount in oysters exposed to OsHV-1 in the field. 


\section{MATERIALS AND METHODS Experimental design}

\section{Ethics Statement}

The Pacific oyster, C. gigas, used in this study is a marine-cultured animal and cultured in the Ifremer facilities in Argenton (Brittany, France; 48 $34^{\prime} 30^{\prime \prime} \mathrm{N}, 4^{\circ} 36^{\prime} 18^{\prime \prime} \mathrm{W}$ ). All of the experiments were conducted according to local and national regulations. Permission for deploying oysters outside of farming areas was issued by the French Ministry of Ecology and Sustainable Development, dept. of maritime affairs, in February 2013. For locations within farming areas, the owner of the farm gave permission to conduct the study on this site. The present field studies did not involve endangered or protected species.

\section{Expt. 1. Validation of a specific antibody directed against $C$. gigas VDAC and tissue-specific analysis of VDAC}

Specific-pathogen-free (SPF) oysters were produced according (Petton et al. 2015). Spawning occurred on 18 August 2014 (cohort NSI 01/15) in Ifremer facilities in Argenton (Brittany, France; 48 $34^{\prime} 30^{\prime \prime} \mathrm{N}, 4^{\circ} 36^{\prime} 18^{\prime}$ ' W). The fecundation rates were up to $90 \%$. The embryos developed in $150 \mathrm{~L}$ tanks at $21^{\circ} \mathrm{C}$ for $48 \mathrm{~h}$, and D-larvae were transferred to flow-through rearing systems at $25^{\circ} \mathrm{C}$. After 15 days, competent larvae were collected and allowed to settle in downwellers. On 6 October 2014, oysters were transferred to Ifremer facilities in Bouin (46 $57^{\prime}$ $\mathrm{N}-2^{\circ} 02^{\prime} \mathrm{O}$ ). Before being transferred to Ifremer facilities in Argenton, oysters were deployed in farming area located in the Bay of Brest at Pointe du Chateau (48 $20^{\circ} 06.19^{\prime}$ N, $4^{\circ} 19^{\prime} 06.37^{\prime}$ ' W) for 11 months since 5 Mars 2015 (Petton et al. 2013). Oysters were sampled on 15 February 
2016. The fleshes of 16 oysters were pooled, flash-frozen, crushed and stored in liquid nitrogen for further validation of the antibody. The mantle, gills, digestive gland, labial palp, striated and smooth adductor muscle, heart and visceral ganglia were carefully dissected from 50 oysters on ice, immediately flash-frozen in liquid nitrogen, pooled together by tissues, crushed and stored in liquid nitrogen.

\section{Expt 2. Quantification of the protein VDAC in oysters exposed to OsHV-1 in the field.} Specific-pathogen-free (SPF) oysters were produced according to Petton et al (Petton et al. 2015). Animals were reared under controlled conditions until the age of 8 months (mean individual wet mass $=0.51 \mathrm{~g}$ ). The oysters were screened for the herpesvirus by qPCR at the different stages of production, and it was undetected in all cases. These SPF oysters (also called "sentinel oysters") were deployed at 46 sites located along an inshore-offshore gradient in the Mor-Braz area, South Brittany (France). This deployment took place before the start of a disease induced mortality event on 8 April 2013 that lasted for 171 days until 26 September 2013 (Pernet et al. in prep). At each site, 16 small mesh bags containing 85 individual oysters were grouped in one big mesh bag. These bags were attached to iron tables for the sites situated in the intertidal farming area or immersed vertically at 2 meters depth and attached to a mooring point for the sites in the offshore area. The oysters were sampled 15 times at each site at low tide slack water \pm 2 hours. Upon arrival in the laboratory, live and dead oysters were counted to evaluate survival. Individual shell length and wet mass were measured on a sub-sample of 25 live oysters per bag. The soft tissues of these oysters were removed from the shells, pooled together, dipped into liquid nitrogen and stored at $-80^{\circ} \mathrm{C}$ until laboratory analyses. Western blot analyses were conducted on samples collected at two inshore sites located within the oyster farming area where mortality occurred the earliest between 7 and 14 June (sites 37 and 39, Fig 1), at two offshore sites where mortality 
occurred later, from 6 to 14 July (sites 33 and 38) and at two sites where no mortality occurred (sites 32 and 36). Analyses were conducted on samples collected before (30 April and 27 May), at the onset (7 and 14 June) and during the earliest mortality event (20 June).

\section{Total protein extraction}

Total protein extraction was performed using $1 \mathrm{~g}$ of oyster powder (flesh or tissues) that was homogenized with a Polytron ${ }^{\circledR}$ PT 2500 E (Kinemetica). Proteins were solubilized during 40 min at $4^{\circ} \mathrm{C}$ by adding $5 \mathrm{~mL}$ of lysis buffer (Guévélou et al. 2013b) (150 mM NaCl, $10 \mathrm{mM}$ Tris pH 7.4, $1 \mathrm{mM}$ EDTA, $1 \mathrm{mM}$ EGTA, $1 \%$ Triton X-100, and 0.5\% Igepal; $\mathrm{pH} 7.4$ at $4{ }^{\circ} \mathrm{C}$ ) containing phosphatase and protease inhibitors (1\% of Phosphatase inhibitor cocktail II [Sigma-Aldrich], 2\% of NaPPi $250 \mathrm{mM}$, and 1 tablet of complete EDTA free protease inhibitor cocktail [Roche] in 25 $\mathrm{mL}$ of lysis buffer). Solubilized proteins were extracted by centrifugation at 4,000 $\mathrm{g}$ for $1 \mathrm{~h}$ at $4^{\circ} \mathrm{C}$ to eliminate lipids and cellular debris. The phase containing proteins was then collected and centrifuged at $10,000 \mathrm{~g}$ for $45 \mathrm{~min}$ at $4^{\circ} \mathrm{C}$. Total protein content in each lysate was analyzed using the DC protein assay (Bio-Rad), in 96-well microplates (Nunc ${ }^{\mathrm{TM}}$ ) using a microplate reader (BioTek®SynergyTM HT). Concentration was obtained using Gen5 version 2.03 software (Bio-Tek). The resulting lysates were divided in aliquots and stored at $-80^{\circ} \mathrm{C}$ for further analysis.

\section{Antibody}

The Crassostrea gigas VDAC protein BAF63641.1 is a 280 amino acids protein with a predicted size of $30.33 \mathrm{kDa}$ and a pI at 8.25 (http://web.expasy.org/compute_pi). A polyclonal anti-Cg VDAC antibody was produced in rabbit by Eurogentec (France) using the protocol describe in (Fabioux et al. 2009), against one peptide (104-QTGTKSGKIKTSYKM-118) located in the middle of the $C$. gigas VDAC protein sequence, in a turn and $\beta$ structure. 
The antibody was purified and analyzed by indirect Elisa against the purified peptide to compare with pre-immune serum, large bleed and final bleed (Eurogentec, France). Purified antiCgVDAC antibody was provided in PBS-BSA $0.1 \%$ with thimerosal $(0.01 \%)$ as preservative and was diluted vol/vol in glycerol for preservation in aliquots at $-20{ }^{\circ} \mathrm{C}$.

\section{Immunodetection on Western-blot}

Immunodetection on western-blot was done after mono-dimensional electrophoresis of total protein lysates: $10 \mu \mathrm{g}, 20 \mu \mathrm{g}$ or $30 \mu \mathrm{g}$. Protein lysates were heated in Laemmli buffer for 10 minutes at $100^{\circ} \mathrm{C}$ and loaded onto $4-15 \%$ SDS-Page (Criterion ${ }^{\circledR}$ TGX ${ }^{\mathrm{TM}}$ Precast Gels Bio-Rad, Hercules, CA, USA) in parallel with broad range SDS-Polyacrylamide gel electrophoresis (PAGE) molecular weight markers (Precision Plus Protein ${ }^{\text {TM} D u a l ~ C o l o r ~ S t a n d a r d, ~ B i o-R a d, ~}$ Hercules, CA, USA). SDS-PAGE run at $200 \mathrm{~V}$ constant voltage, $40 \mathrm{~mA}$, for 10 minutes then 200 V constant voltage, $80 \mathrm{~mA}$, for 40 minutes. Proteins were then transferred onto a PVDF

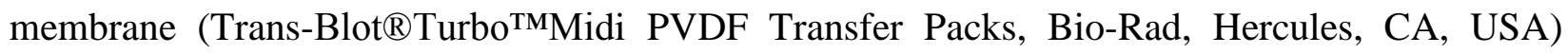

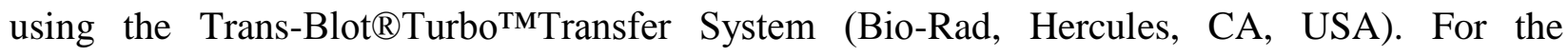
immunodetection, we used the anti Cg-VDAC (Eurogentec; dilution 1:5,000 in PBS-BSA 3\%Tween $1 \%$ ), or the preimmune serum as the primary antibody, overnight at $4{ }^{\circ} \mathrm{C}$. Blots were revealed using a secondary horseradish peroxidase-linked goat anti-rabbit antibody (dilution 1:2500 in PBS-BSA 3\%- Tween 1\%) and a horseradish peroxidase detection kit (GEHealthcare). The relative amount of protein detected was quantified using Gel Imaging for fluorescence and chemiluminescence G:Box Chemi XX6 (Syngene, Gene tools softwareSyngene) with the background signal removed. The value obtained was expressed in OD/mm ${ }^{2}$ and represents the band intensity. To ensure that identical amounts of total protein samples were loaded into gels, membranes were stained 5 minutes with Ponceau S $(0.2 \%$ with TCA $0.3 \%, 5$ - 
sulfosalicylic acid 3\%), then rinsed in distilled water under gentle shaking until the background signal had been removed.

\section{Two-dimensional electrophoresis (2-DE) and immunodetection}

Anti-Cg-VDAC was used for immunodetection on two-dimensional electrophoresis (2-DE) followed by western-blot using mantle, gills, smooth adductor muscle or heart protein lysates. For 2-DE, $500 \mu \mathrm{g}$ of tissue protein lysates were precipitated and desalted by adding 4 volumes of TCA $20 \%$ during $2 \mathrm{~h}$ at $4{ }^{\circ} \mathrm{C}$, followed by centrifugation at $12.000 \mathrm{~g}$ for $15 \mathrm{~min}$ at $4{ }^{\circ} \mathrm{C}$. Pellets were washed 20 times with $80 \%$ acetone in $0.05 \mathrm{M}$ Tris- $\mathrm{HCl}, \mathrm{pH} 8$. Proteins were resuspended in DeStreak rehydration solution (GE Healthcare). Protein concentrations were determined using a modified Bradford assay (Ramagli 1999) and all samples were adjusted to $200 \mu \mathrm{g}$ in $125 \mu \mathrm{l}$ of DeStreak rehydration solution (GE Healthcare) containing 1\% IPG buffer, then samples were placed at room temperature for 1 hour before isoelectric focusing (IEF). The first dimension was

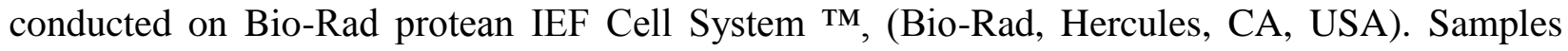
were loaded onto each strip (Immobiline DryStrip pH 4-7, $7 \mathrm{~cm}$, GE Healthcare) and passive rehydration was allowed at room temperature overnight using mineral oil to prevent sample evaporation. The IEF was carried out at $20^{\circ} \mathrm{C}$ in four steps: a calibration step at $250 \mathrm{~V}$ constant voltage for $10 \mathrm{~min}$, an active hydration step at $250 \mathrm{~V}$ for $30 \mathrm{~min}$, a continuous increase in voltage up to $3500 \mathrm{~V}$ over $2 \mathrm{~h}$, then kept at $3500 \mathrm{~V}$ for $2 \mathrm{~h}$. Finally, $50 \mathrm{~V}$ were maintained for $1 \mathrm{~h}$. Before the second dimension, IPG strips were equilibrated for $15 \mathrm{~min}$ in a solution containing $6 \mathrm{M}$ urea, $2 \%$ SDS, 30\% glycerol, and 1\% DTT in $0.05 \mathrm{M}$ Tris-HCL, pH 8.8. The strips were then further equilibrated for 15 min in a similar buffer in which DTT was replaced with $2.5 \%$ iodoacetamide to alkylate the proteins. For the second dimension, $10 \%$ acrylamide gels were used and run on Mini protean tetra cell system (Bio-Rad, Hercules, CA, USA). The gels were loaded with broad 
range SDS-PAGE molecular weight markers (Precision Plus Protein ${ }^{\mathrm{TM}}$ Dual Color Standard, BioRad, Hercules, CA, USA). Migration was carried out at $200 \mathrm{~V}$ constant voltage, $40 \mathrm{~mA}, 10 \mathrm{~min}$, and $200 \mathrm{~V}$ constant voltage, $80 \mathrm{~mA}, 1 \mathrm{~h}$. After 2-DE, immunodetection on western-blot was performed using anti-Cg-VDAC as described above.

\section{Citrate synthase activity}

Citrate synthase (CS; EC 2.3.3.1) activity was measured in oyster tissues using $20 \mu \mathrm{l}$ of total protein lysate obtained as describe before. CS assay buffer contains $100 \mathrm{mM}$ Tris/ $\mathrm{HCl}$ at $\mathrm{pH} 8$, $0.1 \mathrm{mM}$ 5,5'-dithio-bis-[2-nitrobenzoic] acid (DNTB), $0.2 \mathrm{mM}$ acetyl-coenzyme A, and $0.5 \mathrm{mM}$ oxaloacetate. CS activity is measured by following the increase in TNB absorbance for 10 min at $412 \mathrm{~nm}$ using a Synergy HT microplate reader (BioTek). Enzyme activity was related to the total protein concentration of each sample.

\section{Statistical analysis}

Statistical analyses were performed using R software (http://www.R-project.org.). For all tests, the differences were accepted as statistically significant at the $95 \%$ of confidence level $(\mathrm{p}<0.05)$. Linear regressions were used to investigate the relation between VDAC relative protein level (30 $\mathrm{kDa}$ ) and the activity of citrate synthase among tissues (Expt 1). Analyses of Variance (ANOVA) followed by Tukey's post hoc test were conducted to investigate the effect of tissues (Expt 1) and time and sites (Expt 2) on VDAC relative protein levels.

\section{VDAC amino acid sequence comparison}

In order to evaluate the amino acid sequence conservation of the VDAC epitope across bivalves, we searched the VDAC transcript through several transcriptome assemblies. Contigs putatively 
encoding VDAC were identified through BlastX similarity searches against the non-redundant protein sequences database (nr). Coding sequences were predicted by similarity to C. gigas VDAC transcript (AB262088.1) and amino acid sequences were obtained by means of ExPASy translate tool (http://web.expasy.org/tools/translate/). The predicted amino acid sequences are aligned to C. gigas VDAC protein (BAF63641.1) by using BlastP.

\section{RESULTS}

\section{Validation of anti-Cg-VDAC}

As demonstrated by immuno-detection on western-blot, the purified synthetic polyclonal anti-CgVDAC (Eurogentec) strongly and rapidly recognized a band with an apparent molecular weight of $30 \mathrm{kDa}$ in oyster flesh (Fig 1a), which corresponds to the predicted size for VDAC protein in C. gigas (GI:148717311). No signal was revealed when primary antibody was replaced by preimmune serum (Fig 1b). As a result, we validated anti-Cg-VDAC as a specific tool to quantify the amount of VDAC in C. gigas. Anti-Cg-VDAC also detected a signal at around 45, 60 and 90 $\mathrm{kDa}$ (Fig 1a). These signal likely corresponded to the size of multimeric forms of VDAC, i.e. dimers $(60 \mathrm{kDa})$ and trimers $(90 \mathrm{kDa})$. The existence of monomers to tetramers and higher oligomers of VDAC has already been characterized in many other species (Hoogenboom et al. 2007).

\section{Fig 1: Validation of anti-Cg-VDAC antibody.}

Immuno-detection on western-blot with 10 to $30 \mu \mathrm{g}$ of protein lysates from whole-body protein extracts using (a) anti-Cg-VDAC as primary antibody (dilution 1:5000) or (b) by pre-immune serum. VDAC was detected at $30 \mathrm{kDa}$ (arrow), $45 \mathrm{kDa}$ (line), $60 \mathrm{kDa}$ and $90 \mathrm{kDa}$ (asterisks). The 
bands detected at 60 and $90 \mathrm{kDa}$ in SDS PAGE immunoblots correspond to the size of VDAC oligomers.

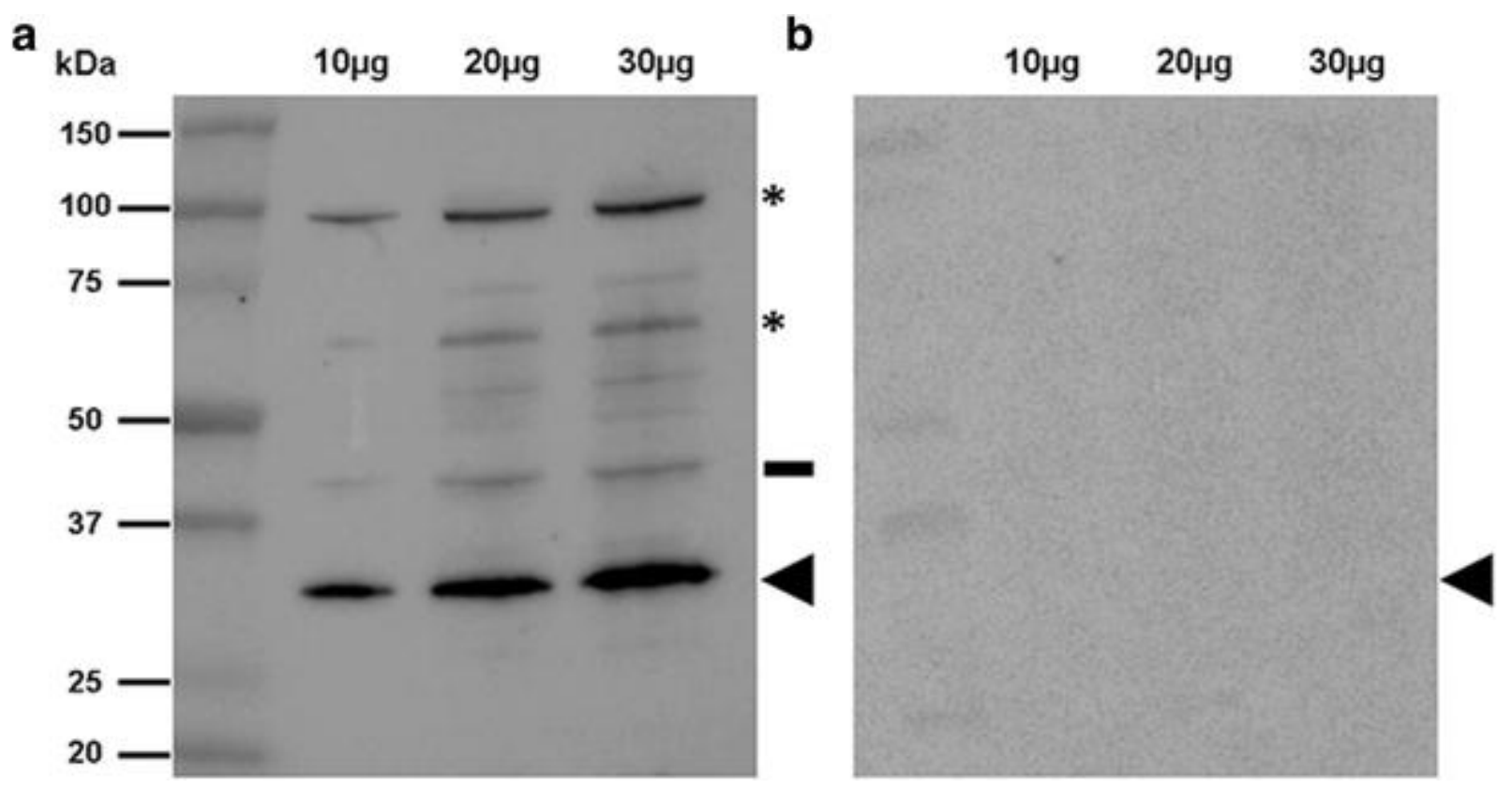

\section{Tissue-specific relative abundance of VDAC}

The $30 \mathrm{kDa}$ VDAC was constitutively expressed in the eight tissues tested (Fig 2) in accordance with the Cg VDAC mRNA expression pattern (Li et al. 2016). Oligomers at $60 \mathrm{kDa}, 90$ and 120 $\mathrm{kDa}$ were also detected at low levels, depending on the tissue (Fig 2a). The $30 \mathrm{kDa}$ VDAC was less abundant in striated and smooth adductor muscle than in other tissues (Fig 2b). Also the electrophoretic profile of VDAC was specific to muscle since VDAC was mainly detected at 45 $\mathrm{kDa}$ rather than at $30 \mathrm{kDa}$ in other tissues. This could be due to muscle-specific post-translational modifications of VDAC such as glycosylation. The relative levels of VDAC among tissues were correlated with their citrate synthase activities ( $\mathrm{p}<0.001$, Fig $2 \mathrm{c})$.

Fig 2: Tissue-specific amount of VDAC and citrate synthase activity.

(a) Immuno-detection on western-blot using anti-Cg VDAC with $10 \mu \mathrm{g}$ of tissues protein lysates and (b) relative quantification of VDAC at $30 \mathrm{kDa}$. Tissues analyzed were: mantle, gills, 
digestive gland, labial palp, striated adductor muscle, smooth adductor muscle, heart and visceral ganglia. VDAC was detected at $30 \mathrm{kDa}$ (arrows), $45 \mathrm{kDa}$ (line), $60 \mathrm{kDa}, 90 \mathrm{kDa}$ or $120 \mathrm{kDa}$ (asterisks) depending on the tissue. The bands detected at 60, 90 and $120 \mathrm{kDa}$ in SDS PAGE immunoblots corresponds to the size of VDAC oligomers. (c) Linear regression model using citrate synthase activity (mU/mg protein) as the explanatory variable and VDAC (30 $\mathrm{kDa})$ relative protein level as the response variable in eight tissues $\left(y=0.086 x+1.178, r^{2}=0.8789\right.$, $\mathrm{p}<0.005)$ 
a
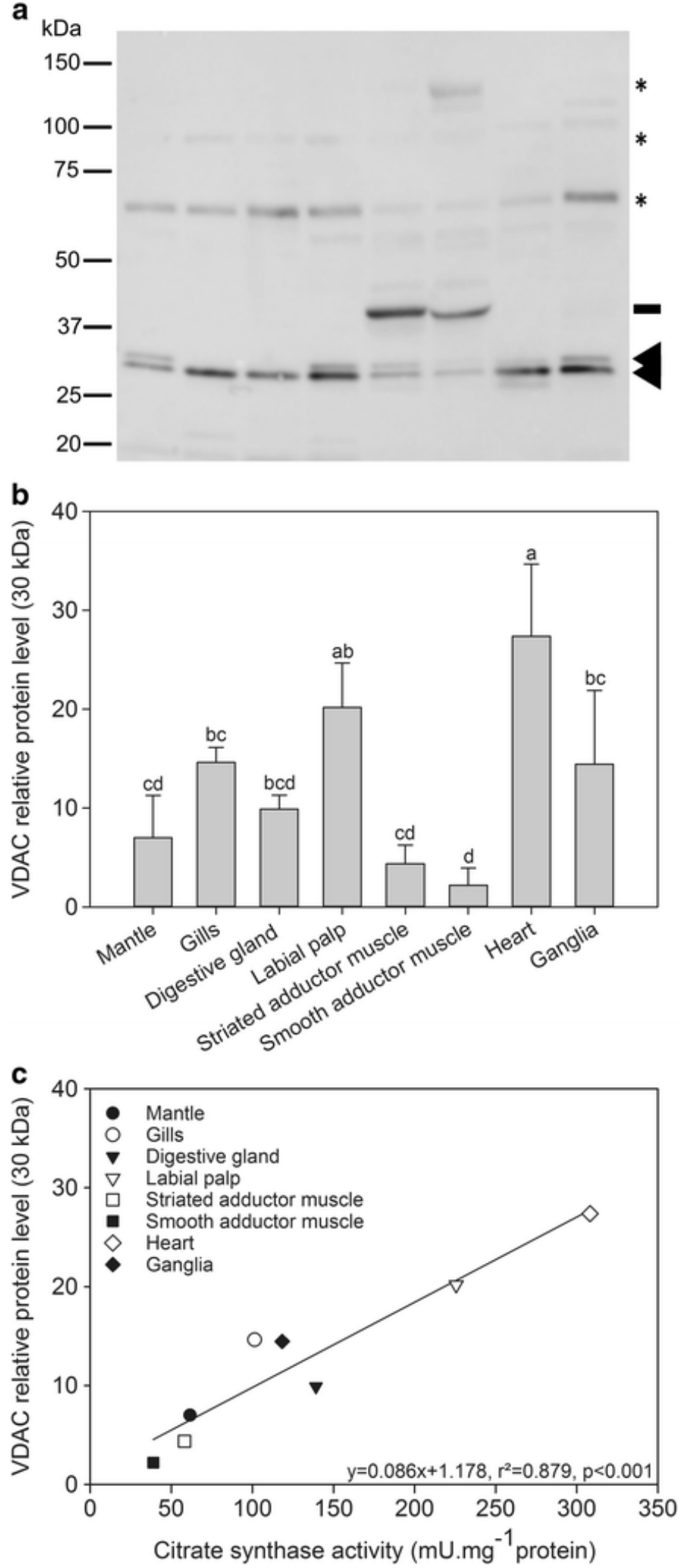


\section{2-DE profile of VDAC}

The immunodetection on western-blot after 2-DE was performed in order to compare the 2-DE electrophoretic profiles of VDAC in four tissues: mantle, gills, smooth adductor muscle and heart (Fig 3). VDAC was detected in one specific train of spots at $30 \mathrm{kDa}$ in the mantle (pI 6.2 to 9.6) and in the gills (pI 7.5 to pI 9.2). In the smooth muscle, the 2-DE profile revealed that VDAC was mainly detected at $45 \mathrm{kDa}$ in a train of spot from pI 6.8 to 7.5 as observed in the monodimensional electrophoresis. In the heart, VDAC was detected in a spot at $30 \mathrm{kDa}(\mathrm{pI}=8$ and 8.3) with a shift at around $32 \mathrm{kDa}(\mathrm{pI}=7.6)$ that might be due to heart-specific posttranslational modifications. In vertebrates, VDAC modifications refer mainly to acetylation, phosphorylation and S-nitrosylation. (Martel et al., 2014). In mammals and plants, VDAC has been found to be phosphorylated (Martel et al., 2014). According to what is known about the structure of VDAC, the horizontal trains on gels could correspond to different phosphorylation states of the protein, and the vertical shifts could be due to glycosylation. In the four tested tissues, the spots detected at $60 \mathrm{kDa}$ or $90 \mathrm{kDa}$ might indicate that some multimerization of VDAC remains visible even after protein denaturation followed by IEF.

\section{Fig 3: Tissue-specific 2-DE profile of VDAC.}

Immuno-detection on western-blot using anti-Cg VDAC after 2-DE with $500 \mu \mathrm{g}$ of (a) mantle, (b) gills, (c) smooth adductor muscle and (d) heart protein lysates. VDAC was detected in spots at $30 \mathrm{kDa}$ (arrows), $45 \mathrm{kDa}$ (line) and $60 \mathrm{kDa}$ (asterisks) depending on the tissue. The spots detected at $60 \mathrm{kDa}$ in 2-DE immunoblots correspond to the size of VDAC dimers. 

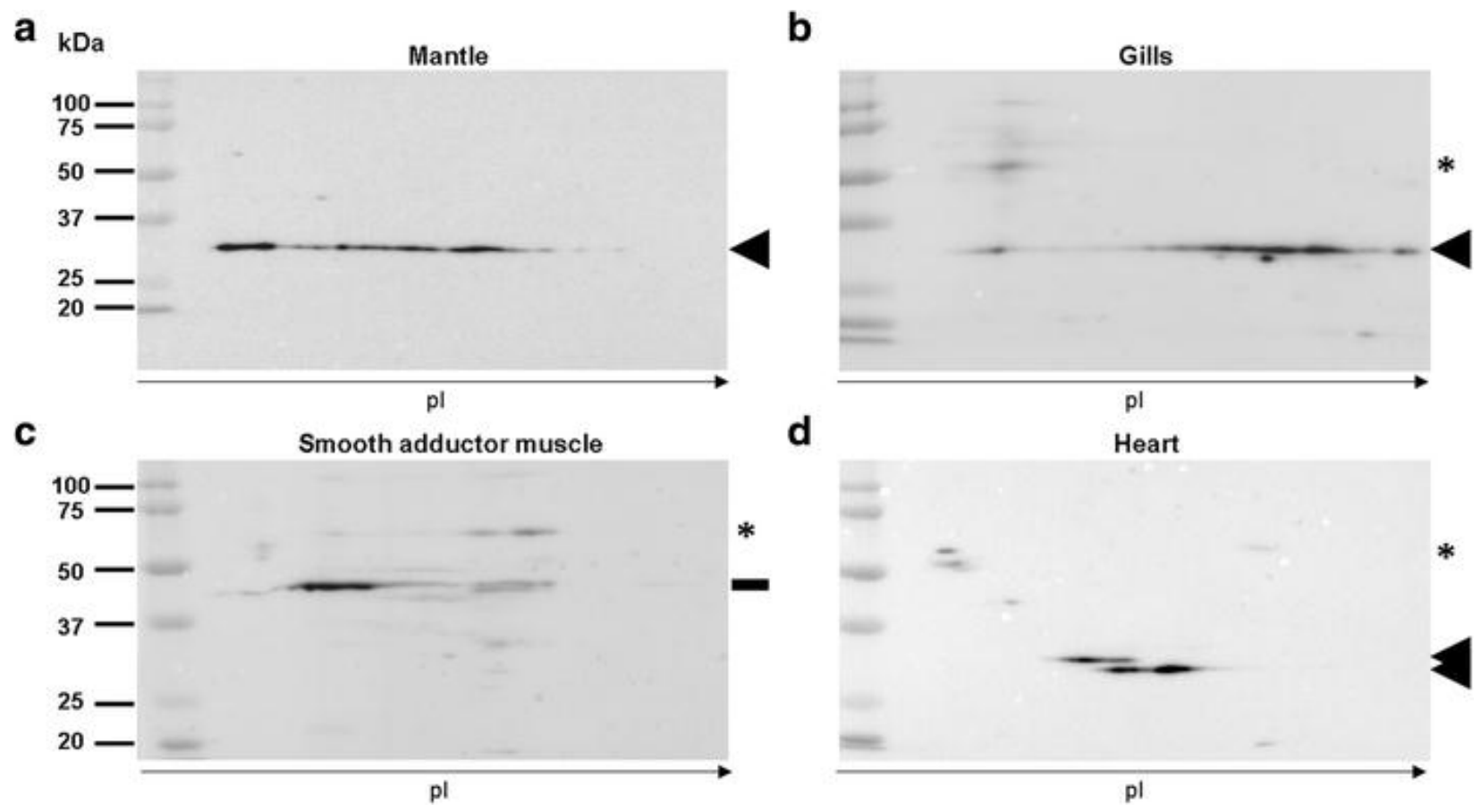

\section{VDAC amount in oysters during a field experiment}

The relative amounts of VDAC were followed in oysters deployed at 6 locations in the field for two months when OsHV-1 outbreaks (Fig 4). The sites 37 and 39 correspond to inshore sites located within the oyster farming area where OsHV-1 induced mortality occurred the earliest between 7 and 14 June (Fig 4a). The sites 33 and 38 were located offshore and OsHV-1 induced mortality occurred later, between 6 to 14 July (Fig 4a). Finally, the sites 32 and 36 were also located offshore, and there was no abnormal mortality (Fig 4a). The levels of VDAC at $30 \mathrm{kDa}$ in oysters varied as a function of sites and time, the interaction of site and time being not significant $(\mathrm{p}=0.081)$. Overall, the level of VDAC at $30 \mathrm{kDa}$ increased with precocity of the mortality event (Fig 4b, 4c, 4d). On 30 April, the levels of VDAC at $30 \mathrm{kDa}$ were similar irrespective of locations (Fig 4d). Then, the level of VDAC at $30 \mathrm{kDa}$ increased between 30 April and 27 May and reached a plateau until 14 June, at the onset of the mortality period (Fig 4c). 


\section{Fig 4: VDAC amount in oysters in the field.}

(a) Map of 6 sampling sites, located along an inshore-offshore gradient in the Mor-Braz area, South Brittany (France). Sites 37 and 39 correspond to sites where mortalities occurred "early" (in red), sites 38 and 33 correspond to sites where mortalities occurred "late" (in yellow), and in sites 36 and 32 "no mortality" (blue) were recorded. (b) Effect of mortality level on the relative level of VDAC (30 kDa) in oysters in early mortality site (red), in late mortality site (yellow), and in site without mortality (blue). (c) Effect of time on the relative level of VDAC (30 kDa) in oysters from 30th April 2013 to 20th June 2013. (d) Representative blocs of western blot obtained the 30th April 2013 and 20th June 2013 in each site using anti-Cg VDAC antibody. 


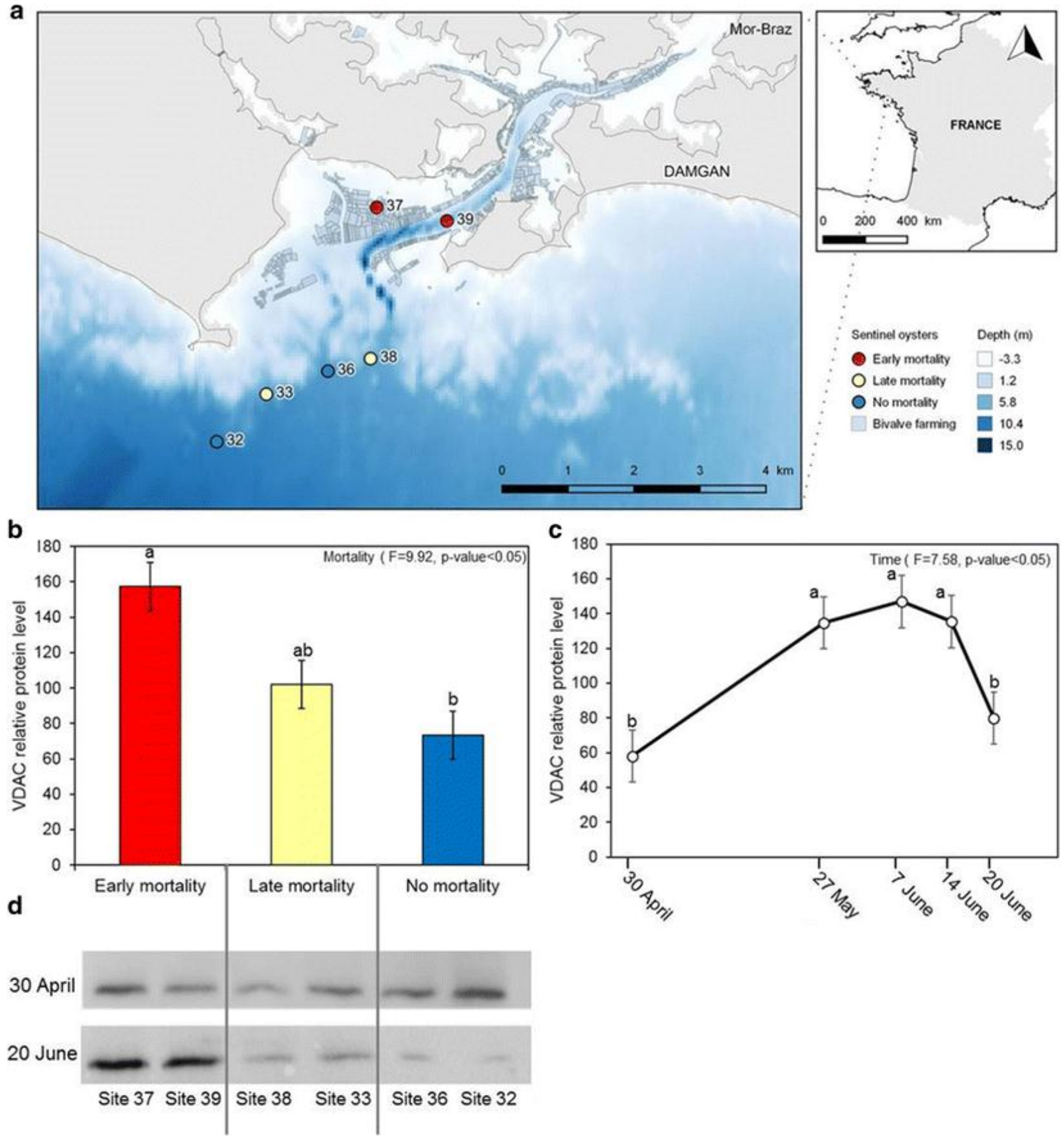

\section{VDAC in other marine species}

We identified a contig encoding VDAC in the transcriptomes of six bivalve species: Crassostrea rhizophorae, Pecten maximus, Ruditapes philippinarum, Ruditapes decussatus, Mytilus galloprovincialis and Mytilus edulis. As compared to C. gigas, the entire VDAC amino-acid 
sequence of the six marine species listed above showed a percentage of identity ranging from 64 to $97 \%$ (Table 1). In these species, we investigated the conservation of the epitope employed for the anti-Cg VDAC antibody synthesis, which consisted of 15 amino acids. With 10 to 14 conserved amino acids in the epitope, we could assume that anti-Cg VDAC antibody might be able to detect VDAC in these bivalve species (Table 1). The best record of epitope conservation was found for $C$. rhizophorae with 14 conserved amino acids.

Table 1: VDAC in C. gigas and other marine species.

\begin{tabular}{|c|c|c|c|}
\hline & $\begin{array}{l}\% \text { identity } \\
C g \text { VDAC }\end{array}$ & Epitope & $\begin{array}{l}\text { Epitope identity } \\
\text { (number aa) }\end{array}$ \\
\hline $\begin{array}{c}C \text { Cg VDAC } \\
\text { Crassostrea gigas }\end{array}$ & - & QTGTKSGKIKTSYKM & - \\
\hline $\begin{array}{c}\text { Cr VDAC } \\
\text { Crassostrea rhizophorae }\end{array}$ & $97 \%$ & QTGTKSGKIKSSYKM & $14 / 15$ \\
\hline $\begin{array}{c}M g \text { VDAC } \\
\text { Mytilus galloprovincialis }\end{array}$ & $67 \%$ & QTGKKQQGTIKTGYKQ & $10 / 15$ \\
\hline $\begin{array}{c}\text { Me VDAC } \\
\text { Mytilus edulis }\end{array}$ & $67 \%$ & QTGKKEQGTIKTGYKQ & $10 / 15$ \\
\hline $\begin{array}{c}\text { Pm VDAC } \\
\text { Pecten maximus }\end{array}$ & $65 \%$ & QTGKKKNGQIKTAYKM & $11 / 15$ \\
\hline $\begin{array}{c}\text { Rp VDAC } \\
\text { Ruditapes philippinarum }\end{array}$ & $64 \%$ & QTGKKSGKV $\underline{\text { KTGYKQ }}$ & $11 / 15$ \\
\hline $\begin{array}{c}R d \text { VDAC } \\
\text { Ruditapes decussatus }\end{array}$ & $64 \%$ & QTGKKSGKVTGFKQ & $10 / 15$ \\
\hline
\end{tabular}


Comparison of VDAC amino acid sequence between $C$. gigas and others marine mollusks (in percentage of identity). The conserved amino acids from the epitope of anti-Cg VDAC are bolt and underlined. Epitope identity is expressed as the number of amino acids conserved with $C$. gigas epitope.

\section{DISCUSSION}

Owing to the purified anti-Cg VDAC antibody developed in our study, we showed that VDAC was constitutively expressed in all the tissues analyzed. This result agrees with the repartition of $C g$ VDAC transcripts in oysters ( $\mathrm{Li}$ et al, 2016). The protein VDAC (30 $\mathrm{kDa})$ was particularly accumulated in the heart, the labial palp, the ganglia, and the gills. The amount of VDAC was correlated with a high activity of citrate synthase in these tissues, a proxy of mitochondria number in tissues (Moran and Manahan 2004; Holmborn et al. 2009).

Analyses of $C g$ VDAC electrophoretic profile using both the western blot and the 2-DE westernblot might reveal the existence of dimers and trimers and their tissue-specific regulations. The detection of bands corresponding to VDAC oligomers can vary between immunoblots, due to either a low level of band detection in a complex protein sample, or to the protocol of denaturation of protein extracts before analysis. VDAC oligomerization is well documented and VDAC is present as a dimer in rat liver (Lindén and Gellerfors 1983), as both dimers and trimmers in yeast (Krause et al. 1986), and higher oligomers in plants (Hoogenboom et al., 2007). In striated and smooth muscles, VDAC was mainly detected at $45 \mathrm{kDa}$ rather than at $30 \mathrm{kDa}$. In fact, specific post-translational modifications of VDAC might occur depending on the tissue, and this was confirmed by 2D immunoblots. Tissue specific regulation of VDAC likely reflects posttranslational modifications, as previously reported in rats (Martel et al. 2014). These authors 
show that various VDAC post-translational modifications can occur, such as phosphorylation, acetylation, S-nitrosylation, and they influence the interactome and the activity of VDAC (Martel et al. 2014). In our case, further analysis should be carried out to verify the identities of the putative post-translational modifications and oligomerization found at 32, 45, 60, 90 and $120 \mathrm{kDa}$ in western blotting. The anti-Cg VDAC antibody developed here might help to study the functioning of VDAC in oyster in further studies designed to investigate the post-translational modifications and oligomerization of $\mathrm{Cg}$ VDAC.

In $C$. gigas, the role of VDAC remains unclear. A recent study strongly supported the well conserved role of VDAC in the control of apoptosis during UV exposure and the direct interaction between VDAC and the pro-apoptotic protein Bak (Li et al. 2016). However, VDAC could be involved in the early stage of viral infection in invertebrates. This was already proposed in C. gigas/OsHV-1 (Corporeau et al. 2014; Young et al. 2017) and demonstrated in shrimps/WSSV. For instance, VDAC is accumulated during WSSV infection in L. vannamei, and it facilitates the infection process (Wang et al. 2007, 2010; Leu et al. 2013). Indeed, when the expression of VDAC is silenced, the infection process is delayed (Chen et al. 2011).

For the first time, our study shows that VDAC is up-accumulated in oysters exposed to OsHV-1 in the field. This result agrees with the accumulation of transcripts of $C g$ VDAC in the hemolymph of oysters infected with OsHV-1 (Renault et al. 2011) six hours after the viral injection ( $\mathrm{Li}$ et al. 2016).

In marine invertebrates, knowledge on proteins playing a role in viral infection is still limited (Li et al. 2016) and studies have mainly explored the host or viral transcriptomes (Jouaux et al. 2013; Segarra et al. 2014). In shrimp, the Warburg effect is induced by viral mechanisms that alter the host metabolome through the PI3K-Akt-mTOR signaling pathways for production of energy and metabolic precursors for viral biogenesis (Su et al. 2014). In shrimp infected by WWSV, VDAC 
is up-regulated, and silencing of VDAC reduces WSSV-induced mortalities and virion copy number (Chen et al., 2011). As a key component of the Warburg effect, it now seems important to develop tools to study VDAC in $C$. gigas at the proteomic level, and to further evaluate its ability to bind partners, like hexokinase, depending on the infection status and the oyster environment.

For the first time, we proved the validity of the anti-Cg VDAC antibody as a tool to follow the amount of VDAC in oyster deployed in the field. We showed that the relative amount of VDAC at $30 \mathrm{kDa}$, as a monomer, can be informative even if it does not represent all the VDAC oligomers. We demonstrated a higher accumulation of VDAC at $30 \mathrm{kDa}$ in tissues exhibiting a higher citrate synthase activity, and in oysters from sites suffering from higher levels of mortality compared to control animals. These results likely indicate that (1) increasing amount of VDAC is related to the susceptibility of oysters to OsHV-1, and (2) disease-susceptibility of oyster and the amount of VDAC in oyster tissues are influenced by the local environment. The high amount of VDAC might reflect the ability of the oyster in the field to shift toward the Warburg effect and to replicate the virus, thus leading to death. Ongoing studies are investigating the role of environmental factors on the interaction between VDAC, C. gigas metabolism and OsHV-1 replication. The antibody anti-Cg VDAC is a new tool to measure the impact of environmental factors on oyster metabolism.

\section{ACKNOWLEDGMENTS}

We are grateful to Ifremer and the French ministry of agriculture for partly supporting this study. We acknowledge E. Harney for his help in editing English. The authors are grateful to Bruno Petton and the ifremer staff involved in oyster and algae production Argenton for their help and 
delivery of animals used in the study. We thank the shellfish network Resco II (http://wwz.ifremer.fr/observatoire_conchylicole).

\section{CONFLICT OF INTEREST}

The author declares no conflict of interest.

\section{REFERENCES}

Barbosa Solomieu V, Renault T, Travers M-A (2015) Mass mortality in bivalves and the intricate case of the Pacific oyster, Crassostrea gigas. J Invertebr Pathol 131:2-10 . doi: 10.1016/j.jip.2015.07.011

Brahimi-Horn MC, Lacas-Gervais S, Adaixo R, et al (2015) Local Mitochondrial-Endolysosomal Microfusion Cleaves Voltage-Dependent Anion Channel 1 To Promote Survival in Hypoxia. Mol Cell Biol 35:1491-1505 . doi: 10.1128/MCB.01402-14

Chen I-T, Aoki T, Huang Y-T, et al (2011) White Spot Syndrome Virus Induces Metabolic Changes Resembling the Warburg Effect in Shrimp Hemocytes in the Early Stage of Infection. J Virol 85:12919-12928 . doi: 10.1128/JVI.05385-11

Corporeau C, Tamayo D, Pernet F, et al (2014) Proteomic signatures of the oyster metabolic response to herpesvirus OsHV-1 $\mu$ Var infection. J Proteomics 109:176-187 . doi: 10.1016/j.jprot.2014.06.030

Davison AJ (2005) A novel class of herpesvirus with bivalve hosts. J Gen Virol 86:41-53 . doi: 10.1099/vir.0.80382-0

Dégremont L (2013) Size and genotype affect resistance to mortality caused by OsHV-1 in Crassostrea gigas. Aquaculture 416-417:129-134 . doi: 10.1016/j.aquaculture.2013.09.011

Delgado T, Carroll PA, Punjabi AS, et al (2010) Induction of the Warburg effect by Kaposi's sarcoma herpesvirus is required for the maintenance of latently infected endothelial cells. Proc Natl Acad Sci 107:10696-10701 . doi: 10.1073/pnas.1004882107

Diamond DL, Syder AJ, Jacobs JM, et al (2010) Temporal Proteome and Lipidome Profiles Reveal Hepatitis C Virus-Associated Reprogramming of Hepatocellular Metabolism and Bioenergetics. PLoS Pathog 6:e1000719 . doi: 10.1371/journal.ppat.1000719

EFSA (2010) Scientific Opinion on the increased mortality events in Pacific oysters, Crassostrea gigas: Oyster mortality

EFSA (2015) Oyster mortality: Oyster mortality. EFSA J 13:4122 . doi: 10.2903/j.efsa.2015.4122 
Fabioux C, Corporeau C, Quillien V, et al (2009) In vivo RNA interference in oyster -vasa silencing inhibits germ cell development. FEBS J 276:2566-2573 . doi: 10.1111/j.1742-4658.2009.06982.x

Guévélou E, Huvet A, Sussarellu R, et al (2013a) Regulation of a truncated isoform of AMP-activated protein kinase $\alpha$ (AMPK $\alpha$ ) in response to hypoxia in the muscle of Pacific oyster Crassostrea gigas. J Comp Physiol [B] 183:597-611 . doi: 10.1007/s00360-013-0743-6

Guévélou E, Huvet A, Sussarellu R, et al (2013b) Regulation of a truncated isoform of AMP-activated protein kinase $\alpha$ (AMPK $\alpha$ ) in response to hypoxia in the muscle of Pacific oyster Crassostrea gigas. J Comp Physiol B 183:597-611 . doi: 10.1007/s00360-013-0743-6

Guo Y, Meng X, Ma J, et al (2014) Human Papillomavirus 16 E6 Contributes HIF-1 $\alpha$ Induced Warburg Effect by Attenuating the VHL-HIF-1 $\alpha$ Interaction. Int J Mol Sci 15:7974-7986 . doi: 10.3390/ijms 15057974

Holmborn T, Dahlgren K, Holeton C, et al (2009) Biochemical proxies for growth and metabolism in Acartia bifilosa (Copepoda, Calanoida). Limnol Oceanogr Methods 7:785-794

Hoogenboom BW, Suda K, Engel A, Fotiadis D (2007) The Supramolecular Assemblies of Voltagedependent Anion Channels in the Native Membrane. J Mol Biol 370:246-255 . doi: 10.1016/j.jmb.2007.04.073

Jouaux A, Lafont M, Blin J-L, et al (2013) Physiological change under OsHV-1 contamination in Pacific oyster Crassostrea gigas through massive mortality events on fields. BMC Genomics 14:590

Krause J, Hay R, Kowollik CH, Brdiczka D (1986) Cross-linking analysis of yeast mitochondrial outer membrane. Biochim Biophys Acta BBA-Biomembr 860:690-698

Lemasters JJ, Holmuhamedov E (2006) Voltage-dependent anion channel (VDAC) as mitochondrial governator-Thinking outside the box. Biochim Biophys Acta BBA - Mol Basis Dis 1762:181-190 . doi: 10.1016/j.bbadis.2005.10.006

Leu J-H, Lin S-J, Huang J-Y, et al (2013) A model for apoptotic interaction between white spot syndrome virus and shrimp. Fish Shellfish Immunol 34:1011-1017 . doi: 10.1016/j.fsi.2012.05.030

Li Y, Zhang L, Qu T, et al (2016) Characterization of Oyster Voltage-Dependent Anion Channel 2 (VDAC2) Suggests Its Involvement in Apoptosis and Host Defense. PLOS ONE 11:e0146049 . doi: 10.1371/journal.pone.0146049

Lindén $M$, Gellerfors $P$ (1983) Hydrodynamic properties of porin isolated from outer membranes of rat liver mitochondria. Biochim Biophys Acta BBA-Biomembr 736:125-129

Lü A-J, Dong C-W, Du C-S, Zhang Q-Y (2007) Characterization and expression analysis of Paralichthys olivaceus voltage-dependent anion channel (VDAC) gene in response to virus infection. Fish Shellfish Immunol 23:601-613 . doi: 10.1016/j.fsi.2007.01.007

Martel C, Wang Z, Brenner C (2014) VDAC phosphorylation, a lipid sensor influencing the cell fate. Mitochondrion 19:69-77 . doi: 10.1016/j.mito.2014.07.009 
Mazure NM (2017) VDAC in cancer. Biochim Biophys Acta BBA - Bioenerg 1858:665-673 . doi: 10.1016/j.bbabio.2017.03.002

Mesri EA, Feitelson MA, Munger K (2014) Human Viral Oncogenesis: A Cancer Hallmarks Analysis. Cell Host Microbe 15:266-282 . doi: 10.1016/j.chom.2014.02.011

Miossec L, Le Deuff R-M, Goulletquer P (2009) Alien species alert: Crassostrea gigas (Pacific oyster). ICES Coop Res Rep 299:

Moran A., Manahan D. (2004) Physiological recovery from prolonged "starvation" in larvae of the Pacific oyster Crassostrea gigas. J Exp Mar Biol Ecol 306:17-36 . doi: 10.1016/j.jembe.2003.12.021

Munger J, Bajad SU, Coller HA, et al (2006) Dynamics of the Cellular Metabolome during Human Cytomegalovirus Infection. PLoS Pathog 2:e132 . doi: 10.1371/journal.ppat.0020132

Naghdi S, Hajnóczky G (2016) VDAC2-specific cellular functions and the underlying structure. Biochim Biophys Acta BBA - Mol Cell Res. doi: 10.1016/j.bbamcr.2016.04.020

Pedersen PL (2007) Warburg, me and Hexokinase 2: Multiple discoveries of key molecular events underlying one of cancers' most common phenotypes, the "Warburg Effect", i.e., elevated glycolysis in the presence of oxygen. J Bioenerg Biomembr 39:211-222 . doi: 10.1007/s10863007-9094-x

Pernet F, Barret J, Le Gall P, et al (2012) Mass mortalities of Pacific oysters Crassostrea gigas reflect infectious diseases and vary with farming practices in the Mediterranean Thau lagoon, France. Aquac Environ Interact 2:215-237 . doi: 10.3354/aei00041

Pernet F, Lupo C, Bacher C, Whittington RJ (2016) Infectious diseases in oyster aquaculture require a new integrated approach. Philos Trans R Soc B Biol Sci 371:20150213 . doi: 10.1098/rstb.2015.0213

Petton B, Pernet F, Robert R, Boudry P (2013) Temperature influence on pathogen transmission and subsequent mortalities in juvenile Pacific oysters Crassostrea gigas. Aquac Environ Interact 3:257-273 . doi: 10.3354/aei00070

Petton, Boudry P, Alunno-Bruscia M, Pernet F (2015) Factors influencing disease-induced mortality of Pacific oysters Crassostrea gigas. Aquac Environ Interact 6:205-222 . doi: 10.3354/aei00125

Poliseno L (2012) Pseudogenes: newly discovered players in human cancer. Sci Signal 5:5

Puyraimond-Zemmour D, Vignot S (2013) Le métabolisme de la cellule tumorale : l'effet Warburg. Oncologie 15:435-440 . doi: 10.1007/s10269-013-2318-2

Ramagli LS (1999) Quantifying protein in 2-D PAGE solubilization buffers. 2- Proteome Anal Protoc 99103

Renault T, Faury N, Barbosa-Solomieu V, Moreau K (2011) Suppression substractive hybridisation (SSH) and real time PCR reveal differential gene expression in the Pacific cupped oyster, Crassostrea gigas, challenged with Ostreid herpesvirus 1. Dev Comp Immunol 35:725-735 . doi: 10.1016/j.dci.2011.02.004 
Rostovtseva TK, Komarov A, Bezrukov SM, Colombini M (2002) VDAC Channels Differentiate between Natural Metabolites and Synthetic Molecules. J Membr Biol 187:147-156 . doi: 10.1007/s00232001-0159-1

Schikorski D, Faury N, Pepin JF, et al (2011) Experimental ostreid herpesvirus 1 infection of the Pacific oyster Crassostrea gigas: Kinetics of virus DNA detection by q-PCR in seawater and in oyster samples. Virus Res 155:28-34 . doi: 10.1016/j.virusres.2010.07.031

Segarra A, Baillon L, Tourbiez D, et al (2014) Ostreid herpesvirus type 1 replication and host response in adult Pacific oysters, Crassostrea gigas. Vet Res 45:103

Segarra A, Pépin JF, Arzul I, et al (2010) Detection and description of a particular Ostreid herpesvirus 1 genotype associated with massive mortality outbreaks of Pacific oysters, Crassostrea gigas, in France in 2008. Virus Res 153:92-99 . doi: 10.1016/j.virusres.2010.07.011

Shen X, Wang T, Xu D, Lu L (2014) Proteomic identification, characterization and expression analysis of Ctenopharyngodon idella VDAC1 upregulated by grass carp reovirus infection. Fish Shellfish Immunol 37:96-107 . doi: 10.1016/j.fsi.2014.01.009

Su M-A, Huang Y-T, Chen I-T, et al (2014) An Invertebrate Warburg Effect: A Shrimp Virus Achieves Successful Replication by Altering the Host Metabolome via the PI3K-Akt-mTOR Pathway. PLoS Pathog 10:e1004196 . doi: 10.1371/journal.ppat.1004196

Vander Heiden MG, Cantley LC, Thompson CB (2009) Understanding the Warburg Effect: The Metabolic Requirements of Cell Proliferation. Science 324:1029-1033 . doi: 10.1126/science.1160809

Wang H-C, Kondo H, Hirono I, Aoki T (2010) The Marsupenaeus japonicus voltage-dependent anion channel (MjVDAC) protein is involved in white spot syndrome virus (WSSV) pathogenesis. Fish Shellfish Immunol 29:94-103 . doi: 10.1016/j.fsi.2010.02.020

Wang H-C, Wang H-C, Leu J-H, et al (2007) Protein expression profiling of the shrimp cellular response to white spot syndrome virus infection. Dev Comp Immunol 31:672-686 . doi: 10.1016/j.dci.2006.11.001

Warburg (1956) On the origin of cancer cells. Science 123:309-314

Young T, Kesarcodi-Watson A, Alfaro AC, et al (2017) Differential expression of novel metabolic and immunological biomarkers in oysters challenged with a virulent strain of OsHV-1. Dev Comp Immunol 73:229-245 . doi: 10.1016/j.dci.2017.03.025 